\title{
Review: evolution of GnlH and related peptides structure and function in the chordates
}

\author{
Tomohiro Osugi ${ }^{\dagger}$, Takayoshi Ubuka and Kazuyoshi Tsutsui* \\ Laboratory of Integrative Brain Sciences, Department of Biology, Center for Medical Life Science, Waseda University, Tokyo, Japan
}

\section{Edited by:}

Sylvie Dufour, Mueum National $d^{\prime}$ Histoire Naturelle, France

\section{Reviewed by:}

Joao Carlos Dos Reis Cardoso, University of Algarve, Portugal Chris Scott, Charles Sturt University, Australia

\section{${ }^{*}$ Correspondence:}

Kazuyoshi Tsutsui, Laboratory of Integrative Brain Sciences,

Department of Biology, Center for

Medical Life Science of Waseda

University, Waseda University, 2-2

Wakamatsu-cho, Shinjuku-ku, Tokyo

162-8480, Japan

e-mail: k-tsutsui@waseda.jp

${ }^{\dagger}$ Present address:

Tomohiro Osugi, Suntory Foundation for Life Sciences, Bioorganic

Research Institute, Osaka, Japan
Discovery of gonadotropin-inhibitory hormone $(\mathrm{GnlH})$ in the Japanese quail in 2000 was the first to demonstrate the existence of a hypothalamic neuropeptide inhibiting gonadotropin release. We now know that $\mathrm{GnlH}$ regulates reproduction by inhibiting gonadotropin synthesis and release via action on the gonadotropin-releasing hormone $(\mathrm{GnRH})$ system and the gonadotrope in various vertebrates. GnlH peptides identified in birds and mammals have a common LPXRF-amide $(X=L$ or $Q$ ) motif at the $\mathrm{C}$-terminus and inhibit pituitary gonadotropin secretion. However, the function and structure of $\mathrm{GnIH}$ peptides are diverse in fish. Goldfish GnIHs possessing a C-terminal LPXRF-amide motif have both stimulatory and inhibitory effects on gonadotropin synthesis or release. The C-terminal sequence of grass puffer and medaka $\mathrm{GnIHs}$ are MPORF-amide. To investigate the evolutionary origin of $\mathrm{GnIH}$ and its ancestral structure and function, we searched for $\mathrm{GnIH}$ in agnathans, the most ancient lineage of vertebrates. We identified $\mathrm{GnIH}$ precursor gene and mature $\mathrm{GnIH}$ peptides with C-terminal QPQRF-amide or RPQRF-amide from the brain of sea lamprey. Lamprey $\mathrm{GnlH}$ fibers were in close proximity to $\mathrm{GnRH}$-III neurons. Further, one of lamprey GnIHs stimulated the expression of lamprey GnRH-III peptide in the hypothalamus and gonadotropic hormone $\beta$ mRNA expression in the pituitary. We further identified the ancestral form of $\mathrm{GnIH}$, which had a C-terminal RPQRF-amide, and its receptors in amphioxus, the most basal chordate species. The amphioxus $\mathrm{GnlH}$ inhibited cAMP signaling in vitro. In sum, the original forms of $\mathrm{GnlH}$ may date back to the time of the emergence of early chordates. GnlH peptides may have had various C-terminal structures slightly different from LPXRF-amide in basal chordates, which had stimulatory and/or inhibitory functions on reproduction. The C-terminal LPXRF-amide structure and its inhibitory function on reproduction may be selected in later-evolved vertebrates, such as birds and mammals.

Keywords: gonadotropin-inhibitory hormone (GnIH), RF-amide peptides, reproduction, evolution, chordates, lamprey, amphioxus

\section{INTRODUCTION}

Reproduction is one of the essential mechanisms for life. In vertebrates, the hypothalamic-pituitary-gonadal (HPG) axis is known as the core mechanism regulating reproduction. Gonadotropinreleasing hormone $(\mathrm{GnRH})$ is the key hypothalamic neuropeptide that regulates the HPG axis by stimulating secretion of gonadotropins, i.e., luteinizing hormone (LH) and folliclestimulating hormone (FSH), from the anterior pituitary. GnRH was first discovered in the brain of mammals at the beginning of 1970s (Matsuo et al., 1971; Burgus et al., 1972), and it was subsequently identified in the brain of non-mammalian vertebrates (King and Millar, 1982; Miyamoto et al., 1982, 1984; Sherwood et al., 1986). On the other hand, until recently no hypothalamic neuropeptide that inhibits gonadotropin release has been identified, although gonadal sex steroids and inhibin can inhibit gonadotropin release.

It became clear that the regulatory mechanism of reproduction is not as simple as it was once considered, since gonadotropininhibitory hormone (GnIH), a novel hypothalamic neuropeptide, was found to be involved in the regulation of the HPG axis (Tsutsui et al., 2000). GnIH was originally identified in birds (Tsutsui et al., 2000) and it was subsequently identified in other vertebrates from fish to humans (for reviews, see Ukena and Tsutsui, 2005; Tsutsui and Ukena, 2006; Tsutsui et al., 2006, 2007, 2010a,b, 2012, 2013; Tsutsui, 2009; Tsutsui and Ubuka, 2012). The discovery of GnIH has now changed our understanding about regulation of the reproductive axis fundamentally (for reviews, see Tsutsui et al., 2006, 2007, 2010a,b, 2012, 2013; Tsutsui, 2009; Tsutsui and Ubuka, 2012; Ubuka et al., 2013a).

To investigate the evolutionary origin of $\mathrm{GnIH}$, we identified the orthologous gene of $\mathrm{GnIH}$ and mature $\mathrm{GnIH}$ peptides in the brain of lamprey, one of the oldest lineage of vertebrates, Agnatha (Osugi et al., 2012). Recently we further identified the ancestral form of GnIH in amphioxus, the most basal chordates (Osugi et al., 2014). These studies suggest that the origin of GnIH-like peptides may date back to the time of the emergence of early chordates. Based on these new findings, this review highlights the evolution of $\mathrm{GnIH}$ peptide structure and its function. 


\section{DISCOVERY OF GnIH IN THE BRAIN AS A NOVEL KEY FACTOR REGULATING REPRODUCTION}

A neuropeptide possessing C-terminal Arg-Phe- $\mathrm{NH}_{2}$ motif (RFamide peptide) was first identified in the ganglia of venus clam Macrocallista nimbosa (Price and Greenberg, 1977). Since important functions of RF-amide peptides as neurotransmitters, neuromodulators or peripheral hormones were revealed in invertebrates (Greenberg and Price, 1992), there have been attempts to identify RF-amide peptides in the central nervous system of vertebrates. Tsutsui et al. (2000) discovered a novel RF-amide peptide from brains of the Japanese quail Coturnix japonica (Tsutsui et al., 2000). An immunohistochemical study showed that the GnIHimmunoreactive cell bodies exist in the paraventricular nucleus (PVN) and their fibers project to the median eminence where neurochemicals that regulate the anterior pituitary are released (Tsutsui et al., 2000). Therefore, this RF-amide peptide was considered to regulate the function of anterior pituitary in quail (Tsutsui et al., 2000). Indeed this novel RF-amide peptide inhibited gonadotropin release from the cultured quail pituitary and thus the RF-amide peptide was termed GnIH (Tsutsui et al., 2000).

Quail GnIH is a dodecapeptide having a C-terminal RFamide motif, SIKPSAYLPLRF-amide (Table 1). The sequence of the five amino acids at the C-terminal of quail GnIH was identical to chicken LPLRF-amide that was isolated as a first RF-amide peptide in vertebrates (Dockray et al., 1983). This chicken LPLRFamide may be a fragment of chicken GnIH (for reviews, see Tsutsui, 2009; Tsutsui et al., 2010a,b). In 2001, a cDNA encoding GnIH precursor polypeptides was identified in quail (Satake et al., 2001). Now GnIH cDNAs have been identified in several avian species, such as chickens, sparrows, starlings and zebra finches (for reviews, see Tsutsui, 2009; Tsutsui et al., 2010a,b). The GnIH precursor encodes one GnIH and two GnIH-related peptides (GnIH-RP-1 and GnIH-RP-2) that possess a conserved Leu-Pro-Xaa-Arg-Phe- $\mathrm{NH}_{2}$ (LPXRF-amide; X = L or Q) motif at their C-termini in all birds studied (Table 1). Thus, GnIH and related peptides are called LPXRF-amide peptides from a structural point of view (for reviews, see Tsutsui, 2009; Tsutsui et al., 2010a,b). GnIH was further isolated as an endogenous ligand in European starling Sturnus vulgaris (Ubuka et al., 2008) and zebra finch Taeniopygia guttata (Tobari et al., 2010) and endogenous GnIH-RP-2 was also identified in quail (Table 1; Satake et al., 2001).

\section{UNITY AND DIVERSITY OF GnIH STRUCTURE IN CHORDATES}

A mammalian GnIH, also known as RFamide-related peptide (RFRP), orthologous gene has been identified by using in silico analysis (Hinuma et al., 2000). The mammalian GnIH cDNAs encoded two GnIH peptides (RFRP-1 and -3) (Table 1 and Figure 1). Human, macaque, bovine and ovine precursor cDNAs also encoded a putative GnIH-like peptide that possesses a C-terminal LPLRSamide or LPLRLamide motif, which was named RFRP-2. However, rodent GnIH precursors lost RFRP-2 (Figure 1) (for reviews, see Tsutsui, 2009; Tsutsui et al., 2010a,b). Interestingly, the putative horse RFRP-2 possesses a C-terminal LPLRFamide motif (Figure 1) (Thorson et al., 2014). The mammalian GnIHs, RFRP-1 and/or RFRP-3, were identified as mature peptides in the brains of bovine Bos taurus (Fukusumi et al., 2001; Yoshida et al., 2003), rat Rattus norvegicus (Ukena et al., 2002), Siberian hamster Phodopus sungorus (Ubuka et al., 2012a), monkey Macaca mulatta (Ubuka et al., 2009a), and human Homo sapiens (Table 1; Ubuka et al., 2009b). GnIH and related peptides identified in birds and mammals have a conserved LPXRF-amide motif at the C-terminus (Table $\mathbf{1}$ ).

In reptiles, a putative GnIH gene was found in the Ensembl genome database of anole lizard, Chinese softshell turtle and painted turtle (Table 1; Figure 1). Recently, the crocodilian genome project was completed and the genome data of American alligator Alligator mississippiensis and saltwater crocodile Crocodylus porosus are available on the website of Crocodilian Genome Project (St. John et al., 2012; http:// crocgenomes.org/). The putative GnIH gene was found in the genome data of crocodilians by using a tblastn program and exonintron calculation based on the GT-AG rule (Figure 1; Mount, 1982). The putative reptilian $\mathrm{GnIH}$ peptides possess a C-terminal LPXRF-amide ( $\mathrm{X}=\mathrm{L}$ or $\mathrm{Q}$ ) motif and showed a high sequence similarity with avian $\mathrm{GnIH}$ peptides that reflects a close phylogenetic position between birds and reptiles (Table 1; Figure 1).

In amphibians, a GnIH peptide was identified in the hypothalamus of bullfrog Rana catesbeiana and named frog growth hormone-releasing peptide (fGRP) (Table 1; Koda et al., 2002). cDNA cloning revealed that the precursor polypeptide encodes four GnIH peptides (fGRP, fGRP-RP-1, -RP-2, and RP-3) (Sawada et al., 2002a). fGRP-RP-1, -RP-2, and RP-3 were also identified as mature peptides (Table 1; Ukena et al., 2003). fGRP was independently isolated from the European green frog Rana esculenta and named Rana RFamide (R-RFa) (Chartrel et al., 2002). A GnIH cDNA was also cloned from the Japanese red-bellied newt, an urodele amphibian (Chowdhury et al., 2011). The deduced precursor encoded four GnIH peptides (nLPXRFa-1, -2, -3, -4), and these peptides were identified as mature peptides from the brain extracts (Table 1; Chowdhury et al., 2011). The rate of amino acid substitution or deletion may have been lower in the lineage of amphibians compared with other vertebrates, resulting in the conservation of four LPXRF-amide ( $\mathrm{X}=\mathrm{L}$ or $\mathrm{Q})$ peptides encoded in the precursor (Figure 1).

In teleost fish, a GnIH cDNA encoding three peptides (gfLPXRFa-1, -2, and -3) which have C-terminal LPXRF-amide $(\mathrm{X}=\mathrm{L}$ or $\mathrm{Q})$ sequences was cloned from the brain of goldfish Carassius auratus, and one peptide (gfLPXRFa-3) was identified as a mature peptide (Table 1; Sawada et al., 2002b). A GnIH gene was also identified in the grass puffer Takifugu niphobles. The grass puffer GnIH precursor contained two putative $\mathrm{GnIH}$ peptides which have C-terminal MPMRF-amide or MPQRFamide sequences and one possible RY-amide peptide (Table 1; Shahjahan et al., 2011). The medaka GnIH precursor contained two putative $\mathrm{GnIH}$ peptides which have C-terminal MPLRFamide or MPQRF-amide sequences and one LPQRF-amide peptide (Table 1; XM_004073848). Therefore, Leu, Met, and Glu are substituted by each other in some fish species. The CUG codon encoding Leu can be mutated to AUG encoding Met by a single nucleotide substitution. Similarly, a single nucleotide substitution in the codon encoding Glu (CAA and CAG) can produce CUA and CUG encoding Leu. Thus, nucleotide substitutions in 
Table 1 | Amino acid sequences of GnIHs in chordates.

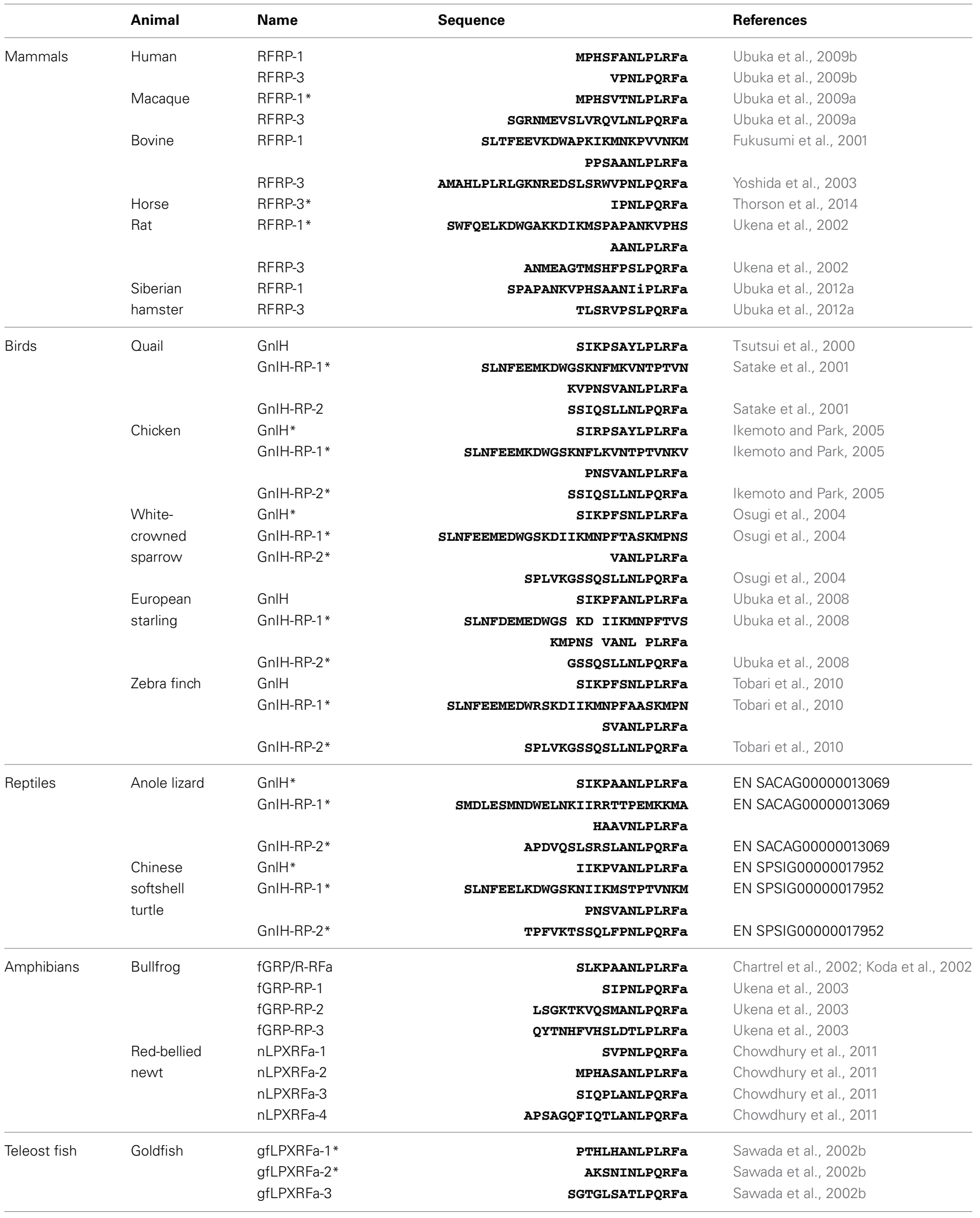


Table 1 | Continued

\begin{tabular}{|c|c|c|c|c|}
\hline & Animal & Name & Sequence & References \\
\hline & \multirow[t]{3}{*}{ Medaka } & mdLPXRFa- ${ }^{*}$ & PLHMHANMPLRFa & XM_004073848 \\
\hline & & mdLPXRFa-2* & VSNSSPNMPQRFa & XM_004073848 \\
\hline & & mdLPXRFa-3* & EAPSPVLPQRFa & XM_004073848 \\
\hline & \multirow[t]{5}{*}{ Grass puffer } & gpLPXRFa-1* & SLDMERINIQVSPTSGKVSLPTIVRLYPT & Shahjahan et al., 2011 \\
\hline & & \multicolumn{3}{|c|}{ LQPHHQHVN } \\
\hline & & \multicolumn{3}{|c|}{-MPMRFa } \\
\hline & & gpLPXRFa-2* & DGVQGGDHVPNLNPNMPQRFa & Shahjahan et al., 2011 \\
\hline & & gpRYa* & SWKVIRLCEDCSKVQGVLKHQVRYa & Shahjahan et al., 2011 \\
\hline \multirow[t]{3}{*}{ Agnathans } & \multirow[t]{3}{*}{ Sea lamprey } & ILPXRFa-la & SGVGQGRSSKTLFQPQRFa & Osugi et al., 2012 \\
\hline & & ILPXRFa-Ib & AALRSGVGQGRSSKTLFQPQRFa & Osugi et al., 2012 \\
\hline & & ILPXRFa-2 & SEPFWHRTRPQRFa & Osugi et al., 2012 \\
\hline \multirow[t]{3}{*}{ Protochordates } & \multirow[t]{3}{*}{ Amphioxus } & PQRFa-1 & WDEAWRPQRFa & Osugi et al., 2014 \\
\hline & & PQRFa-2 & GDHTKDGWRPQRFa & Osugi et al., 2014 \\
\hline & & PQRFa-3 & GRDQGWRPQRFa & Osugi et al., 2014 \\
\hline
\end{tabular}

Ensembl accession numbers or Genbank accession numbers are referred to for reptile GnlHs or medaka GnIHs.

*Indicates putative peptides.

the codon encoding the third and the fifth amino acids from the C-terminal may have occurred in some fish species, such as medaka and grass puffer (Figure 2). We further searched for GnIH-like sequences in the genome database of phylogenetically important fish, such as the elephant shark, skate, and spotted gar. A partial GnIH-like sequence was found in the Ensembl genome database of the spotted gar (chromosome LG11, nt 40715843 to nt 40716142 , reverse strand). The C-terminal motifs of spotted gar GnIH-like peptides were LPLRF or LPQRF and their codons were similar to those of other fish (Figure 2). On the other hand, we could not find any GnIH-like sequence in the elephant shark genome database (http://esharkgenome.imcb.a-star. edu.sg/) and the skate genome database (http://skatebase.org/). Further researches are needed to clarify the presence of $\mathrm{GnIH}$ in cartilaginous fish.

Recently, we have identified a GnIH orthologous gene by using synteny analysis and CDNA cloning in lamprey, one of the most basal vertebrates (Figure 1; Osugi et al., 2012). Mature lamprey $\mathrm{GnIH}$ peptides were also identified by using immunoaffinity purification and mass spectrometry (Table 1; Osugi et al., 2012). The lamprey GnIH peptides possessed a C-terminal QPQRFamide or RPQRF-amide motif and the third or the fifth Leu from the C-terminal was not conserved (Table 1; Osugi et al., 2012). The codon encoding Glu in QPQRF-amide and RPQRFamide were all CAG, and the codon encoding the first Arg in RPQRF-amide was CGG (Figure 2). The codon CAG or CGG can be mutated to CUG encoding Leu by a single nucleotide substitution. Therefore, the fifth and the third Leu from the Cterminal may have appeared and conserved after the emergence of gnathostomes.

We further searched for $\mathrm{GnIH}$ in amphioxus, the most basal chordate, to investigate the evolutionary origin of GnIH. A novel gene encoding RF-amide peptides and mature peptides were identified in the amphioxus Branchiostoma japonicum by using genome database search in Branchiostoma floridae, cDNA cloning and immunoaffinity purification (Table 1; Figure 1; Osugi et al., 2014). The identified amphioxus RF-amide peptides possessed a C-terminal RPQRF-amide motif that was identical to the Cterminal of lamprey LPXRFa-2 (Table 1). The codon encoding the first Arg in RPQRF-amide was CGC, CGA, or CGG, which can be mutated to CUC, CUA, or CUG encoding Leu by a single nucleotide substitution, respectively (Figure 2). The codon encoding the third Glu in RPQRF-amide was CAG or CAA, which can be mutated to CUG or CUA encoding Leu by a single nucleotide substitution, respectively (Figure 2). Accordingly, nucleotide mutations may have occurred at the codon encoding the first Arg and the third Glu in RPQRF-amide during the course of vertebrate evolution, resulting in the C-terminal LPQRF-amide or LPLRF-amide motif of GnIH peptides in gnathostomes.

\section{UNITY AND DIVERSITY OF GnIH FUNCTION IN VERTEBRATE REPRODUCTION}

The function of $\mathrm{GnIH}$ and related peptides are summarized in Table 2. As described above, the gonadotropin inhibiting effect of GnIH was first demonstrated in the quail pituitary in vitro (Tsutsui et al., 2000). An in vivo study further revealed that $\mathrm{GnIH}$ inhibits the release and expression of gonadotropins in quail (Ubuka et al., 2006). In addition to the direct effect of GnIH on the pituitary, GnIH also inhibited GnRH-induced elevation in plasma LH in song sparrow (Osugi et al., 2004). The close proximity of $\mathrm{GnIH}$ immunoreactive fibers to $\mathrm{GnRH}$ neurons and the expression of $\mathrm{GnIH}$ receptor in $\mathrm{GnRH}$ neurons support the effect of GnIH on GnRH neurons in birds (Ubuka et al., 2008). To investigate the mode of action of GnIH in birds, the receptor for GnIH was identified in quail brain (Yin et al., 2005). GnIH receptor (GnIH-R) is a G-protein-coupled receptor, also known as GPR147, and it was expressed in the pituitary and several brain regions including diencephalon (Yin et al., 2005). GnIH-R showed high affinities to GnIH, GnIHRPs, and RFRPs, which have LPXRF-amide $(\mathrm{X}=\mathrm{L}$ or $\mathrm{Q})$ motif 


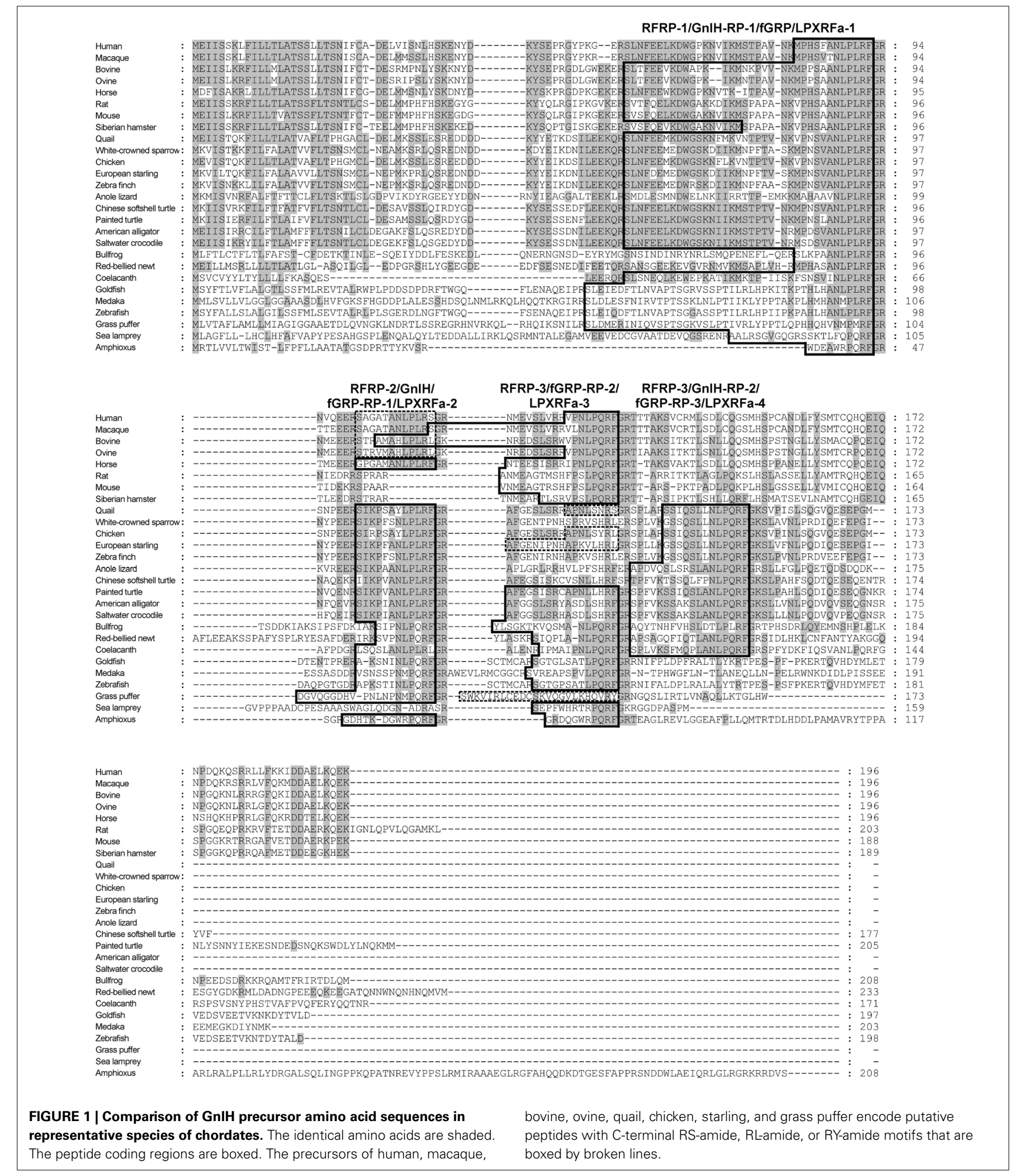

at their C-termini (Yin et al., 2005). Non-amidated GnIH failed to bind the receptor, suggesting that the C-terminal LPXRFamide $(\mathrm{X}=\mathrm{L}$ or $\mathrm{Q})$ motif is responsible for its binding to GnIH-R (Yin et al., 2005). It was further demonstrated that
GnIH-R couples to $\mathrm{G}_{\alpha i}$ and GnIH inhibits GnRH-induced cAMP responsive element (CRE) activation in the chicken, suggesting that GnIH regulates GnRH signaling by inhibiting cAMP signaling pathway (Bédécarrats et al., 2009; Shimizu and Bédécarrats, 


\section{Goldfish LPXRFa-1}

Goldfish LPXRFa-2

Goldfish LPXRFa-3

\section{Medaka LPXRFa-1 \\ Medaka LPXRFa-2 \\ Medaka LPXRFa-3}

\section{Grass puffer LPXRFa-1 \\ Grass puffer LPXRFa-2}

\section{Spotted gar LPXRFa-1}

Spotted gar LPXRFa-2

Spotted gar LPXRFa-3

\section{Lamprey LPXRFa-1a \\ Lamprey LPXRFa-2}

\section{Amphioxus PQRFa-1}

Amphioxus PQRFa-2

Amphioxus PQRFa-3

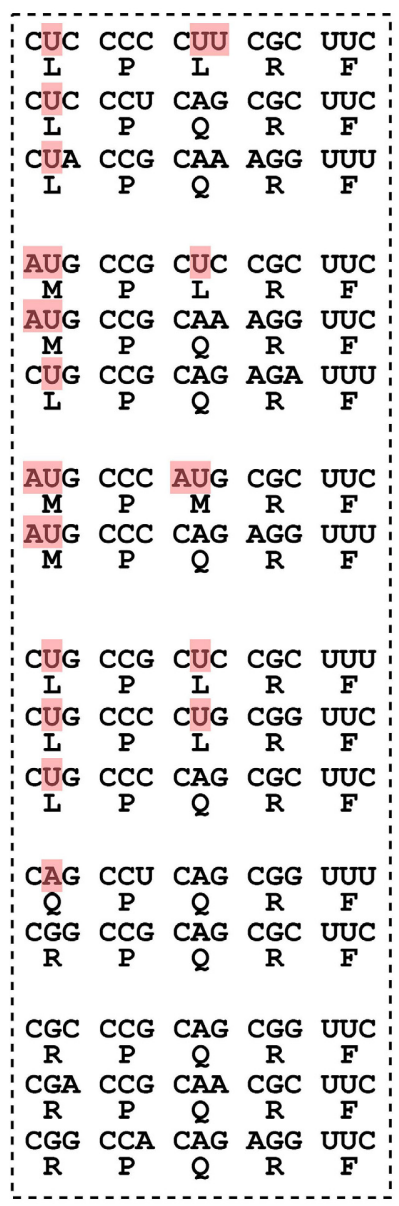

FIGURE 2 | Comparison of the C-terminal five amino acid sequences of GnIH peptides and their corresponding codons in teleost fish (goldfish, medaka, grass puffer, spotted gar), agnathan (lamprey), and

protochordate (amphioxus). The nucleotides that have been modified during evolution are shaded in red.
2010). From the viewpoint of the behavioral regulation, intracerebroventricularly (ICV) administered $\mathrm{GnIH}$ inhibited reproductive behavior of female white-crowned sparrows (Bentley et al., 2006). By using the RNAi technique, it was shown that $\mathrm{GnIH}$ regulates aggressive and sexual behaviors in male white-crowned sparrow or quail (Ubuka et al., 2012b, 2013b). Recently, it was further demonstrated that GnIH inhibits socio-sexual behavior of male quail by increasing neuroestrogen synthesis in the hypothalamus (Ubuka et al., 2014). At the peripheral level, GnIH decreased plasma testosterone concentration, induced testicular apoptosis and decreased spermatogenic activity in adult male quail, suggesting a direct action of $\mathrm{GnIH}$ at the testis or an action via reduced gonadotropin secretion (Ubuka et al., 2006). In addition, $\mathrm{GnIH}$ also reduced the testicular weight in immature birds, suggesting that $\mathrm{GnIH}$ is involved in gonadal development and maintenance (Ubuka et al., 2006). Taken together, GnIH acts as an inhibitory neuropeptide and exerts multiple effects on the reproductive systems in the brain as well as peripheral organs.
In mammals, two GnIH peptides (RFRP-1 and RFRP-3) are encoded in the precursor. As in birds, RFRP-3 inhibited gonadotropin synthesis and/or release in various mammalian species (Kriegsfeld et al., 2006; Johnson et al., 2007; Clarke et al., 2008; Murakami et al., 2008; Kadokawa et al., 2009; Sari et al., 2009; Ubuka et al., 2012a). In addition, immunoreactive GnIH fibers were in close proximity to GnRH neurons in the hypothalamus of human, monkey, sheep, rat and hamster (Kriegsfeld et al., 2006; Johnson et al., 2007; Smith et al., 2008; Ubuka et al., 2009a,b, 2012a). Expression of GnIH-R was also observed in GnRH neurons (Rizwan et al., 2012; Ubuka et al., 2012a). Consistent with histochemical studies, RFRP-3 was shown to inhibit the firing rate of GnRH neurons in mice (Ducret et al., 2009). In pig, RFRP-3 also inhibited the synthesis and release of GnRH (Li et al., 2013). Recently, it was found that ICV administration of RFRP-1 also inhibits gonadotropin release in hamsters (Ubuka et al., 2012a). Therefore, both RFRP-1 and RFRP-3 may act as $\mathrm{GnIH}$ in mammals. Regarding the signal transduction mechanisms in mammals, it was demonstrated that RFRP3 reduces $\mathrm{GnRH}$-stimulated cytoplasmic calcium response and extracellular signal-regulated kinase (ERK) phosphorylation in sheep pituitary (Clarke et al., 2008; Sari et al., 2009). The detailed mechanisms were further investigated using mouse gonadotrope cell line (L $\beta$ T2 cells). It was revealed that the inhibitory action of mouse GnIHs (RFRPs) on gonadotropin gene expression is mediated by an inhibition of adenylate cyclase (AC)/cAMP/cAMPdependent protein kinase A (PKA)-dependent ERK pathway (Son et al., 2012). These studies in mammals suggest that the inhibitory mechanism of GnIH on the reproductive system is conserved among mammalian and avian animals. In Siberian hamsters, the expression of GnIH decreased in short day conditions by the action of pineal melatonin (Ubuka et al., 2012a). Siberian hamster GnIHs (RFRP-1 and RFRP-3) stimulated LH release in short day conditions and inhibited $\mathrm{LH}$ release in long day conditions (Ubuka et al., 2012a). Because Siberian hamsters are long day breeders and short day conditions represent an inhibitory photoperiod, GnIH may sustain appropriate concentration of $\mathrm{LH}$ in short day condition. Taken together, GnIH may have acquired a stimulatory function in the lineage of photoperiodic mammals to optimize their reproductive activities according to the season.

In teleost fish, functional diversity was observed compared to mammals and birds. Goldfish GnIHs (gfLPXRFa peptides) stimulated release of gonadotropins and growth hormone $(\mathrm{GH})$ in Sockeye salmon Oncorhynchus nerka (Amano et al., 2006). In grass puffer, the expression of GnIH and GnIH-R mRNA were increased during the spawning season in the brain and pituitary (Shahjahan et al., 2011). In addition, goldfish $\mathrm{GnIH}$ (gfLPXRFa-1) stimulated the expression of gonadotropin mRNAs in the pituitary in grass puffer, suggesting that $\mathrm{GnIH}$ may be involved in the stimulation of reproductive axis in grass puffer (Shahjahan et al., 2011). In contrast to the stimulatory effects of fish $\mathrm{GnIH}$, zebrafish GnIH decreased serum LH level in goldfish in vivo (Zhang et al., 2010). Similarly, goldfish GnIHs (gfLPXRFa2 and -3 ) decreased salmon GnRH and FSH $\beta$ mRNA levels and gfLPXRFa-2 decreased LH $\beta$ mRNA levels in goldfish in vivo (Qi et al., 2013). Although single administrations of goldfish GnIHs 
Table 2 | Functions of GnIH and related peptides in vertebrates.

\begin{tabular}{|c|c|c|c|}
\hline Animal & Name & Function & References \\
\hline Siberian hamster & RFRP-1 and-3 & Inhibition or stimulation of LH release & Ubuka et al., 2012a \\
\hline Rat & & Inhibition of $\mathrm{GnRH}$-elicited $\mathrm{LH}$ release & Murakami et al., 2008 \\
\hline Mouse & RFRP-3 & Inhibition of the firing rate of $\mathrm{GnRH}$ neurons & Ducret et al., 2009 \\
\hline Bovine & RFRP-3 & Inhibition of LH release & Kadokawa et al., 2009 \\
\hline Pig & RFRP-3 & Inhibition of $\mathrm{GnRH}$ secretion & Li et al., 2013 \\
\hline \multirow[t]{3}{*}{ Quail } & $\mathrm{GnIH}$ & Inhibition of $\mathrm{LH}$ release & Tsutsui et al., 2000 \\
\hline & & Inhibition of gonadotropin secretion & Ubuka et al., 2006 \\
\hline & & Inhibition of socio-sexual behavior & Ubuka et al., 2014 \\
\hline \multirow{3}{*}{ Sparrow } & & Inhibition of reproductive behavior & Bentley et al., 2006 \\
\hline & & Inhibition of aggressive and sexual behaviors & Ubuka et al., 2012b, 2013b \\
\hline & & Inhibition of socio-sexual behavior & Ubuka et al., 2014 \\
\hline Chicken & $\mathrm{GnlH}$ & Inhibition of $\mathrm{GnRH}$-induced $\mathrm{CRE}$ activation & $\begin{array}{l}\text { Bédécarrats et al., 2009; Shimizu } \\
\text { and Bédécarrats, } 2010\end{array}$ \\
\hline \multirow[t]{3}{*}{ Sockeye salmon } & gfLPXRFa-1 & Stimulation of gonadotropin and $\mathrm{GH}$ release & Amano et al., 2006 \\
\hline & gfLPXRFa-2 & Stimulation of gonadotropin and GH release & Amano et al., 2006 \\
\hline & gfLPXRFa-3 & Stimulation of gonadotropin and $\mathrm{GH}$ release & Amano et al., 2006 \\
\hline Grass puffer & gfLPXRFa-1 & Stimulation of gonadotropin expression & Shahjahan et al., 2011 \\
\hline Goldfish & zfLPXRFa & Inhibition of plasma LH concentration & Zhang et al., 2010 \\
\hline
\end{tabular}

(gfLPXRFa-2 and -3) showed no effect on gonadotropin synthesis in the primary culture of goldfish pituitary cells, gfLPXRFa-3 inhibited GnRH-stimulated LH $\beta$ and FSH $\beta$ synthesis (Qi et al., 2013). According to the maturational status of goldfish, goldfish $\mathrm{GnIH}$ exerted both stimulatory and inhibitory effects on the expression of gonadotropin mRNAs and the serum LH level (Moussavi et al., 2012, 2013). The studies in teleost fish suggest that the functions of $\mathrm{GnIH}$ are diverse even within the teleost fish lineage. The action of $\mathrm{GnIH}$ also changes depending on the physiological conditions of the fish.

In agnathans, lamprey GnIH-immunoreactive fibers were in close proximity to GnRH-III neurons (Osugi et al., 2012). One of the GnIH peptides (lamprey LPXRFa-2) administered in vivo increased GnRH-III concentration in the brain and mRNA expression of gonadotropin $\beta$ subunit in the pituitary (Osugi et al., 2012). These effects of GnIH are similar to that of some of teleost fish, suggesting that the stimulatory action of GnIH may have been conserved in several lineages of basal vertebrates.

\section{EVOLUTIONARY ORIGIN OF GnIH AND ITS ANCESTRAL STRUCTURE AND FUNCTION}

Neuropeptide FF (NPFF), also known as PQRF-amide peptide is a pain-modulatory neuropeptide and is considered to be a paralogous gene of GnIH. The C-terminal motifs of $\mathrm{GnIH}$ and NPFF that are important for the interaction with their receptors showed high sequence similarity (Osugi et al., 2006, 2011, 2012). The receptors for GnIH (NPFFR1; GPR147) and NPFF (NPFFR2; GPR74) also showed a high sequence similarity (Yin et al., 2005). In addition, the GnIH gene locates near the HOXA clusters and NPFF gene locates near the HOXC clusters on the chromosome (Figure 3; Ikemoto and Park, 2005; Osugi et al., 2012). The sequence similarity of $\mathrm{GnIH}$ and NPFF and a common belief that the HOX clusters have duplicated from a common ancestral gene during whole genome duplication events through vertebrate evolution (Venkatesh et al., 2007) led to the strong hypothesis that GnIH gene and NPFF gene have diverged from a common ancestral gene through chromosome duplication (Ikemoto and 


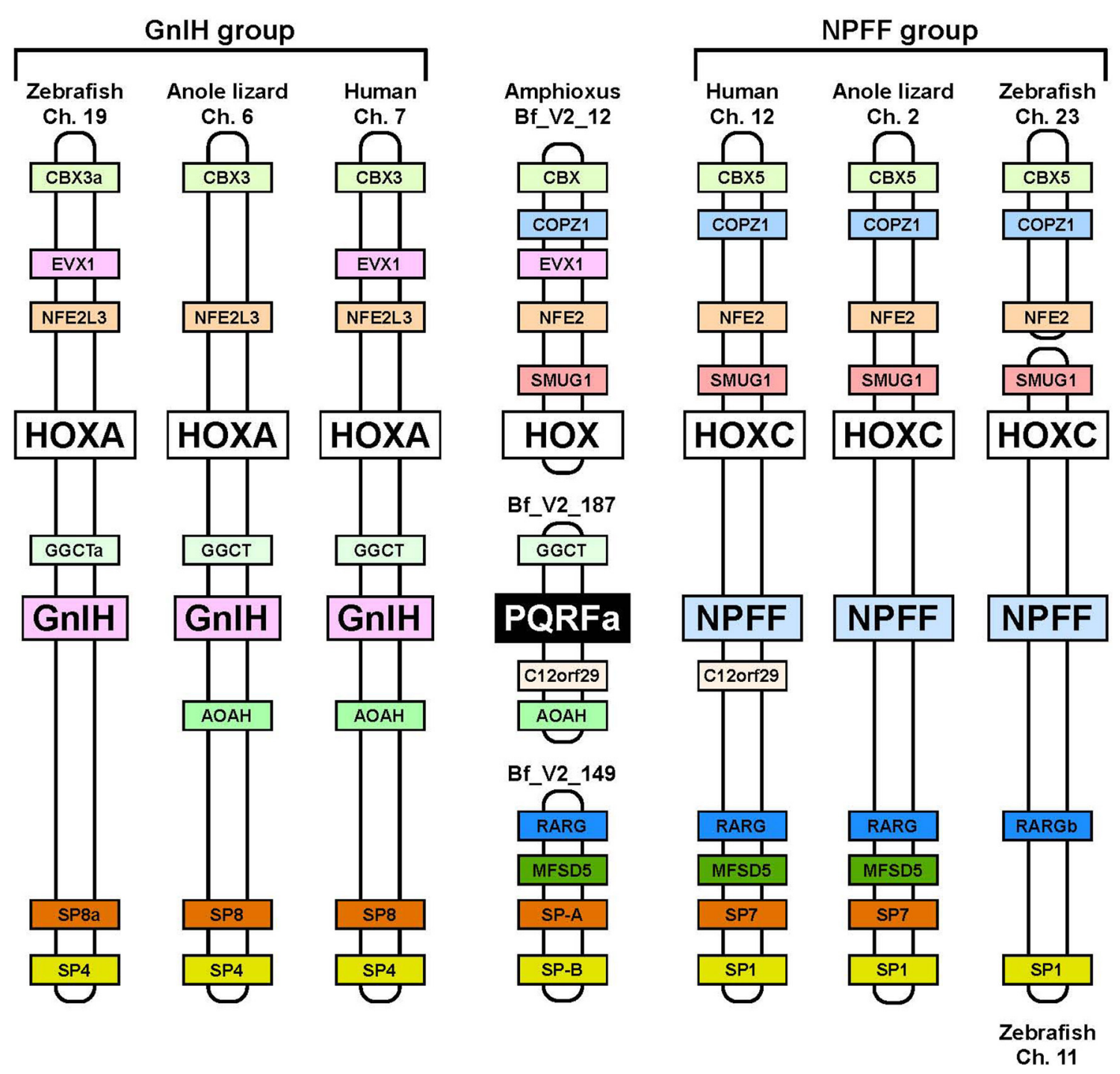

FIGURE 3 | Synteny analysis of the loci of amphioxus PQRF-amide peptide gene, GnIH gene, and NPFF gene. The names of animals and chromosome or scaffold numbers are shown on the top or bottom of each chromosome or scaffold region. Orthologous genes are shown in a same color. The amphioxus PQRF-amide peptide gene, vertebrate $\mathrm{GnIH}$ genes and vertebrate NPFF genes are shown in black, pink, or blue boxes. HOX clusters are shown in white boxes. The conserved synteny region exists around the loci of amphioxus PQRF-amide peptide gene, GnlH gene and NPFF gene. The distance of the genome fragments analyzed were as follows: $15.08 \mathrm{Mbp}$ (human Ch. 7), 17.24 Mbp (anole lizard Ch. 6), 18.46 Mbp (zebrafish Ch. 19), $1.09 \mathrm{Mbp}$ (human Ch. 12), $3.91 \mathrm{Mbp}$ (anole lizard Ch. 2), $40 \mathrm{Kbp}$ (zebrafish Ch. 23), and 259.76 Mbp (zebrafish Ch. 11). Note that anole lizard HOXA and SP8 are on the scaffolds GL343275.1 and GL343212.1. The homology between these genome regions was identified based on the gene annotation in the Ensembl genome database. The homologous genes of amphioxus were searched by the blast program in the Joint Genome Institute.
Park, 2005; Osugi et al., 2012, 2014). The presence of both GnIH and NPFF in agnathans, the most ancient vertebrates, further suggests that GnIH and NPFF genes have diverged before the emergence of vertebrates (Osugi et al., 2006, 2011, 2012). As described above, we identified a novel gene encoding RF-amide peptides and mature peptides in the amphioxus Branchiostoma japonicum (Table 1; Figure 1; Osugi et al., 2014). We further identified putative receptors for the identified amphioxus RF-amide peptides. Molecular phylogenetic analysis and synteny analysis indicated that these genes are closely related to GnIH and NPFF genes and their receptors of vertebrates (Figure 3; Osugi et al.,
2014). The identified amphioxus RF-amide peptides inhibited forskolin induced cAMP signaling in the COS-7 cells transfected with one of the identified amphioxus RF-amide peptide receptors (Osugi et al., 2014). The study of amphioxus thus indicates that the identified protochordate RF-amide peptide gene is likely to be an ancestral form of both GnIH and NPFF. We could not find any GnIH-like peptide sequence in other early deuterostome genomes, such as Ciona intestinalis, sea urchin and acorn worm. Therefore, the origin of GnIH may date back to the time of the emergence of early chordates (Figure 4). The role of the ancestral GnIH may have been an inhibitory peptide and its functions 


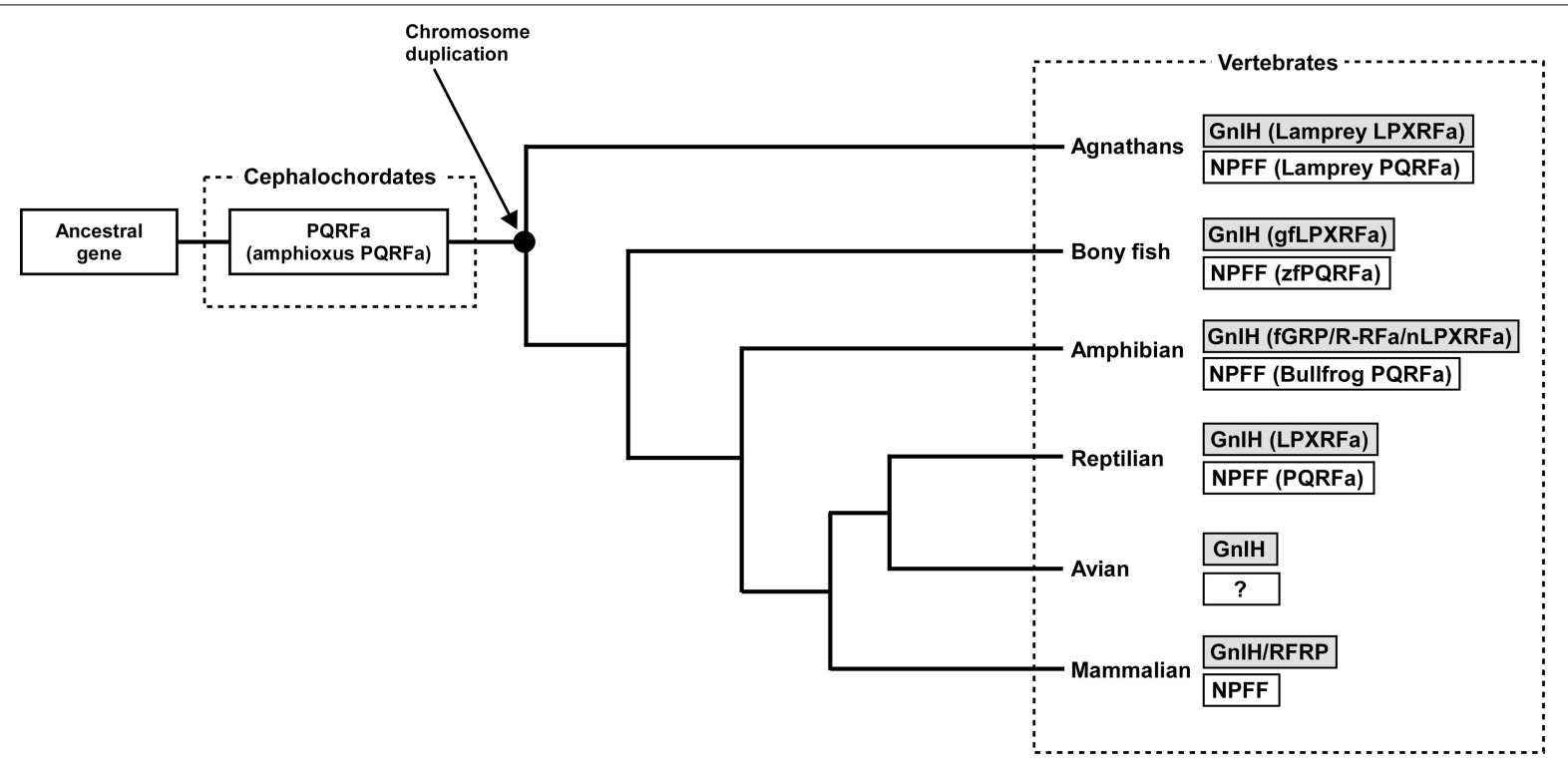

FIGURE 4 | Proposed evolutionary history of GnIH and NPFF genes. GnIH and NPFF genes may have originated from a common ancestral gene. The amphioxus which has not experienced chromosome duplication has sustained an ancestral form of GnIH and NPFF genes. GnIH and NPFF genes may have evolved through chromosome duplication that has occurred at the beginning of vertebrate evolution. ?, unknown. may have been diversified in some lineage during the course of vertebrate evolution.

Currently, the following RF-amide peptide groups, namely, GnIH, NPFF, 26RF-amide peptide (26RFa)/pyroglutamylated RF-amide peptide (QRFP), prolactin-releasing peptide (PrRP), Kiss1, and Kiss2 are found in the brain of vertebrates (Tsutsui, 2009; Tsutsui et al., 2010b). Within these groups, GnIH and NPFF, and Kiss1 and Kiss2 are thought to be paralogous (Felip et al., 2009; Lee et al., 2009; Osugi et al., 2012, 2013, 2014; Pasquier et al., 2012). It is of interest to investigate the evolutionary relationship between RF-amide peptide groups, and search the common origin of these RF-amide peptides. Recent advances in genome database with powerful instruments, such as bioinformatic tools and next-generation sequencing, may enable us to analyze the genome data of various animals and answer to this question.

\section{ACKNOWLEDGMENTS}

This work was supported in part by Grants-in-Aid for Scientific Research from the Ministry of Education, Science and Culture, Japan (18107002, 22132004, and 22227002 to Kazuyoshi Tsutsui).

\section{REFERENCES}

Amano, M., Moriyama, S., Iigo, M., Kitamura, S., Amiya, N., Yamamori, K., et al. (2006). Novel fish hypothalamic neuropeptides stimulate the release of gonadotrophins and growth hormone from the pituitary of sockeye salmon. J. Endocrinol. 188, 417-423. doi: 10.1677/joe.1.06494

Bédécarrats, G. Y., McFarlane, H., Maddineni, S. R., and Ramachandran, R. (2009). Gonadotropin-inhibitory hormone receptor signaling and its impact on reproduction in chickens. Gen. Comp. Endocrinol. 163, 7-11. doi: 10.1016/j.ygcen.2009.03.010

Bentley, G. E., Jensen, J. P., Kaur, G. J., Wacker, D. W., Tsutsui, K., and Wingfield, J. C. (2006). Rapid inhibition of female sexual behavior by gonadotropin-inhibitory hormone (GnIH). Horm. Behav. 49, 550-555. doi: 10.1016/j.yhbeh.2005.12.005
Burgus, R., Butcher, M., Amoss, M., Ling, N., Monahan, M., Rivier, J., et al. (1972) Primary structure of the ovine hypothalamic luteinizing hormone-releasing factor (LRF). Proc. Natl. Acad. Sci. U.S.A. 69, 278-282. doi: 10.1073/pnas.69.1.278

Chartrel, N., Dujardin, C., Leprince, J., Desrues, L., Tonon, M. C., Cellier, E., et al. (2002). Isolation, characterization, and distribution of a novel neuropeptide, Rana RFamide (R-RFa), in the brain of the European green frog Rana esculenta. J. Comp. Neurol. 448, 111-127. doi: 10.1002/ cne. 10253

Chowdhury, V. S., Ubuka, T., Osugi, T., Shimura, T., and Tsutsui, K. (2011). Identification, localization and expression of LPXRFamide peptides, and melatonin-dependent induction of their precursor mRNA in the newt brain. J. Endocrinol. 209, 211-220. doi: 10.1530/JOE-10-0494

Clarke, I. J., Sari, I. P., Qi, Y., Smith, J. T., Parkington, H. C., Ubuka, T., et al. (2008). Potent action of RFamide-related peptide- 3 on pituitary gonadotropes indicative of a hypophysiotropic role in the negative regulation of gonadotropin secretion. Endocrinology 149, 5811-5821. doi: 10.1210/en.2008-0575

Dockray, G. J., Reeve, J. R. Jr., Shively, J., Gayton, R. J., and Barnard, C. S. (1983). A novel active pentapeptide from chicken brain identified by antibodies to FMRFamide. Nature 305, 328-330. doi: 10.1038/305328a0

Ducret, E., Anderson, G. M., and Herbison, A. E. (2009). RFamide-related peptide-3, a mammalian gonadotropin-inhibitory hormone ortholog, regulates gonadotropin-releasing hormone neuron firing in the mouse. Endocrinology 150, 2799-2804. doi: 10.1210/en.2008-1623

Felip, A., Zanuy, S., Pineda, R., Pinilla, L., Carrillo, M., Tena-Sempere, M., et al. (2009). Evidence for two distinct KiSS genes in non-placental vertebrates that encode kisspeptins with different gonadotropin-releasing activities in fish and mammals. Mol. Cell. Endocrinol. 312, 61-71. doi: 10.1016/j.mce.2008.11.017

Fukusumi, S., Habata, Y., Yoshida, H., Iijima, N., Kawamata, Y., Hosoya, M., et al. (2001). Characteristics and distribution of endogenous RFamiderelated peptide-1. Biochim. Biophys. Acta. 1540, 221-232. doi: 10.1016/S01674889(01)00135-5

Greenberg, M. J., and Price, D. A. (1992). Relationships among the FMRFamidelike peptides. Prog. Brain Res. 92, 25-37. doi: 10.1016/S0079-6123(08)61162-0

Hinuma, S., Shintani, Y., Fukusumi, S., Iijima, N., Matsumoto, Y., Hosoya, M., et al. (2000). New neuropeptides containing carboxy-terminal RFamide and their receptor in mammals. Nat. Cell Biol. 2, 703-708. doi: 10.1038/35036326

Ikemoto, T., and Park, M. K. (2005). Chicken RFamide-related peptide (GnIH) and two distinct receptor subtypes: identification, molecular characterization, and evolutionary considerations. J. Reprod. Dev. 51, 359-377. doi: 10.1262/jrd.16087 
St. John, J. A., Braun, E. L., Isberg, S. R., Miles, L. G., Chong, A. Y., Gongora, J., et al. (2012). Sequencing three crocodilian genomes to illuminate the evolution of archosaurs and amniotes. Genome Biol. 13:415. doi: 10.1186/gb-201213-1-415

Johnson, M. A., Tsutsui, K., and Fraley, G. S. (2007). Rat RFamide-related peptide-3 stimulates GH secretion, inhibits $\mathrm{LH}$ secretion, and has variable effects on sex behavior in the adult male rat. Horm. Behav. 51, 171-180. doi: 10.1016/j.yhbeh.2006.09.009

Kadokawa, H., Shibata, M., Tanaka, Y., Kojima, T., Matsumoto, K., Oshima, K., et al. (2009). Bovine C-terminal octapeptide of RFamide-related peptide-3 suppresses luteinizing hormone (LH) secretion from the pituitary as well as pulsatile LH secretion in bovines. Domest. Anim. Endocrinol. 36, 219-224. doi: 10.1016/j.domaniend.2009.02.001

King, J. A., and Millar, R. P. (1982). Structure of chicken hypothalamic luteinizing hormone-releasing hormone. I. Structural determination on partially purified material. J. Biol. Chem. 257, 10722-10728.

Koda, A., Ukena, K., Teranishi, H., Ohta, S., Yamamoto, K., Kikuyama, S., et al. (2002). A novel amphibian hypothalamic neuropeptide: isolation, localization, and biological activity. Endocrinology 143, 411-419. doi: 10.1210/endo.143.2.8630

Kriegsfeld, L. J., Mei, D. F., Bentley, G. E., Ubuka, T., Mason, A. O., Inoue, K., et al. (2006). Identification and characterization of a gonadotropin-inhibitory system in the brains of mammals. Proc. Natl. Acad. Sci. U.S.A. 103, 2410-2415. doi: 10.1073/pnas.0511003103

Lee, Y. R., Tsunekawa, K., Moon, M. J., Um, H. N., Hwang, J. I., Osugi, T., et al. (2009). Molecular evolution of multiple forms of kisspeptins and GPR54 receptors in vertebrates. Endocrinology 150, 2837-2846. doi: 10.1210/en.2008-1679

Li, X., Su, J., Fang, R., Zheng, L., Lei, R., Wang, X., et al. (2013). The effects of RFRP-3, the mammalian ortholog of $\mathrm{GnIH}$, on the female pig reproductive axis in vitro. Mol. Cell. Endocrinol. 372, 65-72. doi: 10.1016/j.mce.2013.03.015

Matsuo, H., Baba, Y., Nair, R. M., Arimura, A., and Schally, A. V. (1971). Structure of the porcine LH- and FSH-releasing hormone. I. The proposed amino acid sequence. Biochem. Biophys. Res. Commun. 43, 1334-1339. doi: 10.1016/S0006291X(71)80019-0

Miyamoto, K., Hasegawa, Y., Minegishi, T., Nomura, M., Takahashi, Y., Igarashi, M., et al. (1982). Isolation and characterization of chicken hypothalamic luteinizing hormone-releasing hormone. Biochem. Biophys. Res. Commun. 107, 820-827. doi: 10.1016/0006-291X(82)90596-4

Miyamoto, K., Hasegawa, Y., Nomura, M., Igarashi, M., Kangawa, K., and Matsuo, H. (1984). Identification of the second gonadotropin-releasing hormone in chicken hypothalamus: evidence that gonadotropin secretion is probably controlled by two distinct gonadotropin-releasing hormones in avian species. Proc. Natl. Acad. Sci. U.S.A. 81, 3874-3878. doi: 10.1073/pnas.81.12.3874

Mount, S. M. (1982). A catalogue of splice junction sequences. Nucleic Acids Res. 10, 459-472. doi: 10.1093/nar/10.2.459

Moussavi, M., Wlasichuk, M., Chang, J. P., and Habibi, H. R. (2012). Seasonal effect of GnIH on gonadotrope functions in the pituitary of goldfish. Mol. Cell. Endocrinol. 350, 53-60. doi: 10.1016/j.mce.2011.11.020

Moussavi, M., Wlasichuk, M., Chang, J. P., and Habibi, H. R. (2013). Seasonal effect of gonadotrophin inhibitory hormone on gonadotrophin-releasing hormoneinduced gonadotroph functions in the goldfish pituitary. J. Neuroendocrinol. 25, 506-516. doi: 10.1111/jne.12024

Murakami, M., Matsuzaki, T., Iwasa, T., Yasui, T., Irahara, M., Osugi, T., et al. (2008). Hypophysiotropic role of RFamide-related peptide-3 in the inhibition of LH secretion in female rats. J. Endocrinol. 199, 105-112. doi: 10.1677/JOE08-0197

Osugi, T., Daukss, D., Gazda, K., Ubuka, T., Kosugi, T., Nozaki, M., et al. (2012). Evolutionary origin of the structure and function of gonadotropininhibitory hormone: insights from lampreys. Endocrinology 153, 2362-2374. doi: 10.1210/en.2011-2046

Osugi, T., Ohtaki, N., Sunakawa, Y., Son, Y. L., Ohkubo, M., Iigo, M., et al. (2013). Molecular evolution of kiss2 genes and peptides in vertebrates. Endocrinology 154, 4270-4280. doi: 10.1210/en.2012-2267

Osugi, T., Okamura, T., Son, Y. L., Ohkubo, M., Ubuka, T., Henmi, Y., et al. (2014). Evolutionary origin of GnIH and NPFF in chordates: insights from novel amphioxus RFamide peptides. PLoS ONE 9:e100962. doi: 10.1371/journal.pone. 0100962

Osugi, T., Uchida, K., Nozaki, M., and Tsutsui, K. (2011). Characterization of novel RFamide peptides in the central nervous system of the brown hagfish: isolation, localization, and functional analysis. Endocrinology 152, 4252-4264. doi: 10.1210/en.2011-1375

Osugi, T., Ukena, K., Bentley, G. E., O’Brien, S., Moore, I. T., Wingfield, J. C., et al. (2004). Gonadotropin-inhibitory hormone in Gambel's white-crowned sparrow (Zonotrichia leucophrys gambelii): cDNA identification, transcript localization and functional effects in laboratory and field experiments. J. Endocrinol. 182, 33-42. doi: 10.1677/joe.0.1820033

Osugi, T., Ukena, K., Sower, S. A., Kawauchi, H., and Tsutsui, K. (2006). Evolutionary origin and divergence of PQRFamide peptides and LPXRFamide peptides in the RFamide peptide family. Insights from novel lamprey RFamide peptides. FEBS J. 273, 1731-1743. doi: 10.1111/j.1742-4658.2006.05187.x

Pasquier, J., Lafont, A. G., Tostivint, H., Vaudry, H., Rousseau, K., and Dufour, S. (2012). Comparative evolutionary histories of kisspeptins and kisspeptin receptors in vertebrates reveal both parallel and divergent features. Front. Endocrinol. (Lausanne) 3:173. doi: 10.3389/fendo.2012.00173

Price, D. A., and Greenberg, M. J. (1977). Structure of a molluscan cardioexcitatory neuropeptide. Science 197, 670-671. doi: 10.1126/science.877582

Qi, X., Zhou, W., Li, S., Lu, D., Yi, S., Xie, R., et al. (2013). Evidences for the regulation of GnRH and GTH expression by GnIH in the goldfish, Carassius auratus. Mol. Cell. Endocrinol. 366, 9-20. doi: 10.1016/j.mce.2012.11.001

Rizwan, M. Z., Poling, M. C., Corr, M., Cornes, P. A., Augustine, R. A., Quennell, J. H., et al. (2012). RFamide-related peptide-3 receptor gene expression in GnRH and kisspeptin neurons and GnRH-dependent mechanism of action. Endocrinology 153, 3770-3779. doi: 10.1210/en.2012-1133

Sari, I. P., Rao, A., Smith, J. T., Tilbrook, A. J., and Clarke, I. J. (2009). Effect of RF-amide-related peptide-3 on luteinizing hormone and folliclestimulating hormone synthesis and secretion in ovine pituitary gonadotropes. Endocrinology150, 5549-5556. doi: 10.1210/en.2009-0775

Satake, H., Hisada, M., Kawada, T., Minakata, H., Ukena, K., and Tsutsui, K. (2001). Characterization of a cDNA encoding a novel avian hypothalamic neuropeptide exerting an inhibitory effect on gonadotropin release. Biochem. J. 354, 379-385. doi: 10.1042/0264-6021:3540379

Sawada, K., Ukena, K., Kikuyama, S., and Tsutsui, K. (2002a). Identification of a cDNA encoding a novel amphibian growth hormone-releasing peptide and localization of its transcript. J. Endocrinol. 174, 395-402. doi: 10.1677/joe.0.1740395

Sawada, K., Ukena, K., Satake, H., Iwakoshi, E., Minakata, H., and Tsutsui, K. (2002b). Novel fish hypothalamic neuropeptide. Eur. J. Biochem. 269, 6000-6008. doi: 10.1046/j.1432-1033.2002.03351.x

Shahjahan, M., Ikegami, T., Osugi, T., Ukena, K., Doi, H., Hattori, A., et al. (2011). Synchronised expressions of LPXRFamide peptide and its receptor genes: seasonal, diurnal and circadian changes during spawning period in grass puffer. J. Neuroendocrinol. 23, 39-51. doi: 10.1111/j.1365-2826.2010.02081.x

Sherwood, N. M., Sower, S. A., Marshak, D. R., Fraser, B. A., and Brownstein., M. J. (1986). Primary structure of gonadotropin-releasing hormone in lamprey brain. J. Biol. Chem. 15, 4812-4819.

Shimizu, M., and Bédécarrats, G. Y. (2010). Activation of the chicken gonadotropin-inhibitory hormone receptor reduces gonadotropin releasing hormone receptor signaling. Gen. Comp. Endocrinol. 167, 331-337. doi: 10.1016/j.ygcen.2010.03.029

Smith, J. T., Coolen, L. M., Kriegsfeld, L. J., Sari, I. P., Jaafarzadehshirazi, M. R., Maltby, M., et al. (2008). Variation in kisspeptin and RFamiderelated peptide (RFRP) expression and terminal connections to gonadotropinreleasing hormone neurons in the brain: a novel medium for seasonal breeding in the sheep. Endocrinology 149, 5770-5782. doi: 10.1210/en. 2008-0581

Son, Y. L., Ubuka, T., Millar, R. P., Kanasaki, H., and Tsutsui, K. (2012). Gonadotropin-inhibitory hormone inhibits GnRH-induced gonadotropin subunit gene transcriptions by inhibiting AC/cAMP/PKA-dependent ERK pathway in L $\beta$ T2 cells. Endocrinology 153, 2332-2343. doi: 10.1210/en.2011-1904

Thorson, J. F., Prezotto, L. D., Cardoso, R. C., Sharpton, S. M., Edwards, J. F., Welsh, T. H. Jr., et al. (2014). Hypothalamic distribution, adenohypophyseal receptor expression, and ligand functionality of RFamide-related peptide 3 in the mare during the breeding and nonbreeding seasons. Biol. Reprod. 90, 28. doi: 10.1095/biolreprod.113.112185

Tobari, Y., Iijima, N., Tsunekawa, K., Osugi, T., Okanoya, K., Tsutsui, K., et al. (2010). Identification of gonadotropin-inhibitory hormone in the zebra finch (Taeniopygia guttata): Peptide isolation, cDNA cloning and brain distribution. Peptides 31, 816-826. doi: 10.1016/j.peptides.2010.01.015 
Tsutsui, K. (2009). A new key neurohormone controlling reproduction, gonadotropin-inhibitory hormone $(\mathrm{GnIH})$ : Biosynthesis, mode of action and functional significance. Prog. Neurobiol. 88, 76-88. doi: 10.1016/j.pneurobio.2009.02.003

Tsutsui, K., Bentley, G. E., Bedecarrats, G. T., Osugi, T., Ubuka, T., and Kriegsfeld, L. J. (2010a). Gonadotropin-inhibitory hormone (GnIH) and its control of central and peripheral reproductive function. Front. Neuroendocrinol. 31, 284-295. doi: 10.1016/j.yfrne.2010.03.001

Tsutsui, K., Bentley, G. E., Kriegsfeld, L. J., Osugi, T., Seong, J. Y., and Vaudry, H. (2010b). Discovery and evolutionary history of gonadotrophin-inhibitory hormone and kisspeptin: new key neuropeptides controlling reproduction. J. Neuroendocrinol. 22, 716-727. doi: 10.1111/j.1365-2826.2010.02018.x

Tsutsui, K., Bentley, G. E., Ubuka, T., Saigoh, E., Yin, H., Osugi, T., et al. (2007). The general and comparative biology of gonadotropin-inhibitory hormone $(\mathrm{GnIH})$. Gen. Comp. Endocrinol. 153, 365-370. doi: 10.1016/j.ygcen.2006.10.005

Tsutsui, K., Saigoh, E., Ukena, K., Teranishi, H., Fujisawa, Y., Kikuchi, M., et al. (2000). A novel avian hypothalamic peptide inhibiting gonadotropin release. Biochem. Biophys. Res. Commun. 275, 661-667. doi: 10.1006/bbrc.2000.3350

Tsutsui, K., and Ubuka, T. (2012). "Gonadotropin-inhibitory hormone," in Handbook of biologically active peptides, eds A. J. Kastin and H. Vaudry (London: Academic Press), 802-811.

Tsutsui, K., Ubuka, T., Bentley, G. E., and Kriegsfeld, L. J. (2012). Gonadotropininhibitory hormone $(\mathrm{GnIH})$ : discovery, progress and prospect. Gen. Comp. Endocrinol. 177, 305-314. doi: 10.1016/j.ygcen.2012.02.013

Tsutsui, K., Ubuka, T., Bentley, G. E., and Kriegsfeld, L. J. (2013). Regulatory mechanisms of gonadotropin-inhibitory hormone $(\mathrm{GnIH})$ synthesis and release in photoperiodic animals. Front. Neurosci. 7:60. doi: 10.3389/fnins.2013.00060

Tsutsui, K., Ubuka, T., Yin, H., Osugi, T., Ukena, K., Bentley, G. E., et al. (2006). Mode of action and functional significance of avian gonadotropin-inhibitory hormone (GnIH). J. Exp. Zool. 305A, 801-806. doi: 10.1002/jez.a.305

Tsutsui, K., and Ukena, K. (2006). Hypothalamic LPXRF-amide peptides in vertebrates: identification, localization and hypophysiotropic activity. Peptides 27, 1121-1129. doi: 10.1016/j.peptides.2005.06.036

Ubuka, T., Haraguchi, S., Tobari, Y., Narihiro, M., Ishikawa, K., Hayashi, T., et al. (2014). Hypothalamic inhibition of socio-sexual behaviour by increasing neuroestrogen synthesis. Nat. Commun. 5, 3061. doi: 10.1038/ncomms4061

Ubuka, T., Inoue, K., Fukuda, Y., Mizuno, T., Ukena, K., Kriegsfeld, L. J., et al. (2012a). Identification, expression, and physiological functions of Siberian hamster gonadotropin-inhibitory hormone. Endocrinology 153, 373-385. doi: 10.1210/en.2011-1110

Ubuka, T., Kim, S., Huang, Y. C., Reid, J., Jiang, J., Osugi, T., et al. (2008). Gonadotropin-inhibitory hormone neurons interact directly with gonadotropin-releasing hormone-I and -II neurons in European starling brain. Endocrinology 149, 268-278. doi: 10.1210/en.2007-0983

Ubuka, T., Lai, H., Kitani, M., Suzuuchi, A., Pham, V., Cadigan, P. A., et al. (2009a). Gonadotropin-inhibitory hormone identification, cDNA cloning, and distribution in rhesus macaque brain. J. Comp. Neurol. 517, 841-855. doi: 10.1002/cne.22191

Ubuka, T., Mizuno, T., Fukuda, Y., Bentley, G. E., Wingfield, J. C., and Tsutsui, K. (2013b). RNA interference of gonadotropin-inhibitory hormone gene induces aggressive and sexual behaviors in birds. Gen. Comp. Endocrinol. 181, 179-186. doi: 10.1016/j.ygcen.2012.09.010

Ubuka, T., Morgan, K., Pawson, A. J., Osugi, T., Chowdhury, V. S., Minakata, H., et al. (2009b). Identification of human GnIH homologs, RFRP-1 and RFRP-3, and the cognate receptor, GPR147 in the human hypothalamic pituitary axis. PLoS ONE 4:e8400. doi: 10.1371/journal.pone.0008400
Ubuka, T., Mukai, M., Wolfe, J., Beverly, R., Clegg, S., Wang, A., et al. (2012b). RNA interference of gonadotropin-inhibitory hormone gene induces arousal in songbirds. PLoS ONE 7:e30202. doi: 10.1371/journal.pone. 0030202

Ubuka, T., Son, Y. L., Bentley, G. E., Millar, R. P., and Tsutsui, K. (2013a). Gonadotropin-inhibitory hormone $(\mathrm{GnIH}), \mathrm{GnIH}$ receptor and cell signaling. Gen. Comp. Endocrinol. 190, 10-17. doi: 10.1016/j.ygcen.2013. 02.030

Ubuka, T., Ukena, K., Sharp, P. J., Bentley, G. E., and Tsutsui, K. (2006). Gonadotropin-inhibitory hormone inhibits gonadal development and maintenance by decreasing gonadotropin synthesis and release in male quail. Endocrinology 147, 1187-1194. doi: 10.1210/en.2005-1178

Ukena, K., Iwakoshi, E., Minakata, H., and Tsutsui, K. (2002). A novel rat hypothalamic RFamide-related peptide identified by immunoaffinity chromatography and mass spectrometry. FEBS Lett. 512, 255-258. doi: 10.1016/S00145793(02)02275-5

Ukena, K., Koda, A., Yamamoto, K., Kobayashi, T., Iwakoshi-Ukena, E., Minakata, H., et al. (2003). Novel neuropeptides related to frog growth hormonereleasing peptide: isolation, sequence, and functional analysis. Endocrinology 144, 3879-3884. doi: 10.1210/en.2003-0359

Ukena, K., and Tsutsui, K. (2005). A new member of the hypothalamic RF-amide peptide family, LPXRF-amide peptides: structure, localization, and function. Mass Spectrom. Rev. 24, 469-486. doi: 10.1002/mas.20031

Venkatesh, B., Kirkness, E. F., Loh, Y. H., Halpern, A. L., Lee, A. P., Johnson, J., et al. (2007). Survey sequencing and comparative analysis of the elephant shark (Callorhinchus milii) genome. PLoS Biol. 5:e101. doi: 10.1371/journal.pbio.0050101

Yin, H., Ukena, K., Ubuka, T., and Tsutsui, K. (2005). A novel G protein-coupled receptor for gonadotropin-inhibitory hormone in the Japanese quail (Coturnix japonica): identification, expression and binding activity. J. Endocrinol. 184, 257-266. doi: 10.1677/joe.1.05926

Yoshida, H., Habata, Y., Hosoya, M., Kawamata, Y., Kitada, C., and Hinuma, S. (2003). Molecular properties of endogenous RFamide-related peptide-3 and its interaction with receptors. Biochim. Biophys. Acta. 1593, 151-157. doi: 10.1016/S0167-4889(02)00389-0

Zhang, Y., Li, S., Liu, Y., Lu, D., Chen, H., Huang, X., et al. (2010). Structural diversity of the $\mathrm{GnIH} / \mathrm{GnIH}$ receptor system in teleost: its involvement in early development and the negative control of LH release. Peptides 31, 1034-1043. doi: 10.1016/j.peptides.2010.03.003

Conflict of Interest Statement: The authors declare that the research was conducted in the absence of any commercial or financial relationships that could be construed as a potential conflict of interest.

Received: 10 June 2014; accepted: 29 July 2014; published online: 15 August 2014. Citation: Osugi T, Ubuka T and Tsutsui K (2014) Review: evolution of GnIH and related peptides structure and function in the chordates. Front. Neurosci. 8:255. doi: 10.3389/fnins.2014.00255

This article was submitted to Neuroendocrine Science, a section of the journal Frontiers in Neuroscience.

Copyright (c) 2014 Osugi, Ubuka and Tsutsui. This is an open-access article distributed under the terms of the Creative Commons Attribution License (CC BY). The use, distribution or reproduction in other forums is permitted, provided the original author(s) or licensor are credited and that the original publication in this journal is cited, in accordance with accepted academic practice. No use, distribution or reproduction is permitted which does not comply with these terms. 